\title{
Current Research on the Structure and Function of the Growth Hormone Releasing Hormone Receptor
}

\author{
Bruce Gaylinn \\ Division of Endocrinology, University of Virginia Health System
}

\begin{abstract}
Growth hormone releasing hormone receptor (GHRH-R) is a family B1 G-protein coupled receptor found predominantly on pituitary somatotrophs. In the adults it is required for the normal synthesis and release of growth hormone $(\mathrm{GH})$ from the pituitary. During development it is required for the normal proliferation and maturation of somatotrophs within the pituitary. Mutations of this receptor in mouse and man are associated with GH deficiency, short stature and pituitary hypoplasia. This signaling system plays important roles in growth and development, metabolism of muscle and fat, and is implicated in the regulation of cardiac and immune function, wound healing, tumor growth and the aging process. Current areas of active research discussed here include: studiesof the structure of the receptor binding site and its interaction with GHRH, alternative splice variants of the GHRH-R which appear to promote tumor proliferation, truncated receptor isoforms that act as dominant negative inhibitors of wild type receptor, and the unclear physiologic role of the GHRH system in birds and fishes. (J Kor Soc Endocrinol 21:173 183, 2006)
\end{abstract}

\section{Background}

The growth hormone releasing hormone receptor (GHRH-R) is found predominantly on the somatotroph of the anterior pituitary[1,2]. In its classic physiologic pathway, GHRH produced by neurons in the arcuate nucleus of the hypothalamus is released from the median eminence and delivered to the pituitary by the pituitary portal circulation[3]. Here GHRH acts at the GHRH-R of somatotrophs to trigger both the synthesis and release of growth hormone (GH)[4]. The actions of GHRH are opposed by somatostatin and potentiated by ghrelin (a GH secretagogue), each acting at its own somatotroph receptor[5]. The integrated response to these signals is a complex pulsatile pattern of GH release to the peripheral circulation. During development GHRH is required for normal somatotroph proliferation and maturation[6]. After birth, GH acting both directly and through stimulation of hepatic IGF-I, is required for normal postnatal postural growth[3]. Genetic defects of the GHRH-R have been shown to be a cause of $\mathrm{GH}$ deficient dwarfism[7 14].

Besides its role in postural growth, GH acts throughout life as a regulator of metabolism and nutrient partitioning acting anabolically (in opposition to glucocorticoids) to favor increased muscle and decreased fat, as a required factor for muscle growth in response to exercise, and to protect against muscle loss in starvation[15 17].

The GHRH/GH/IGF-1 system is also reported to have a variety of other actions throughout the body including stimulation of increased bone mineral mass[18], immune function[19], wound healing[20], heart function[21,22], skin thickness[23], sleep[24] and psychological well being [25,26]. GH levels are regulated by diet and exercise[27] and after puberty decrease steadily with age[28]. Consistent with its mitogenic effect on somatotrophs[29], GHRH is hypothesized to act as a local autocrine/ paracrine factor whose local release by tumor cells may play a role in tumor growth and proliferation[30 32].

The Growth hormone releasing hormone receptor (GHRH-R) is a member of the class B1 family of G-protein coupled receptors (GPCRs), also known as class II or secretin-like hormone receptors. This is an ancient protein family with members found throughout the vertebrates, insects, worms, and possibly even plants[33]. 
Human Hormone Receptors of Family B1

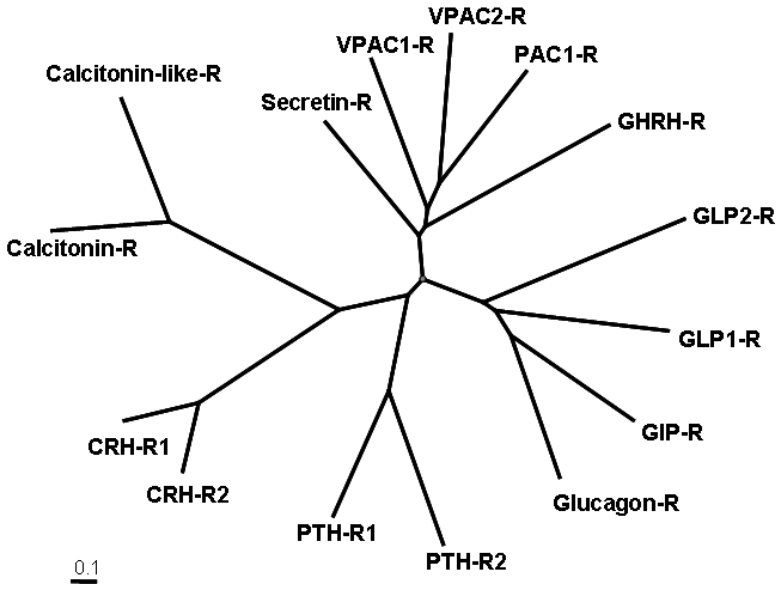

Fig. 1. Phylogenetic distance tree derived from computer alignment of amino acid sequences of human family B1 hormone receptors. Branch points represent statistically chosen hypothetical common ancestral sequences. Branch lengths are proportional to the number of amino acid changes from that hypothetical sequence. Scale bar indicates 0.1 changes per amino acid. $\mathrm{PAC}_{1}-\mathrm{R}$, PACAP specific receptor; $\mathrm{VPAC}_{1}-\mathrm{R}, \mathrm{PACAP} / \mathrm{VIP}$ receptor type 1 ; $\mathrm{VPAC}_{2}-\mathrm{R}, \mathrm{PACAP}$ /VIP receptor type 2.

Analysis of the human genome[34] confirms that this family encompasses a small distinct group of receptors (15 human genes) with very little sequence similarity to the large main family of rhodopsin-like (class I, family A) G protein coupled receptors which has hundreds of members (752 human genes).

Family B1 GPCRs (Fig. 1) include the known receptors for a family of peptides homologous to GHRH. These peptides include secretin, glucagon, glucagon-like peptides (GLP-1, GLP-2), vasoactive intestinal peptide (VIP), pituitary adenylate cyclase-activating peptide (PACAP), PACAP-related peptide (PRP), peptide histidine -methionine (PHM in the human, PHI in species where the C-terminal residue is isoleucine), and glucose-dependent insulinotrophic polypeptide (GIP, also called gastric inhibitory peptide)[35 37]. These homologous peptides can, to varying extents, cross-react at each other's receptors[35].

The secretin receptor was the first class II GPCR to be cloned, allowing analysis of its sequence and structure[38]. The GHRH-R was then cloned based on its sequence homology to the secretin receptor[1,2,39]. The human GHRH-R gene is made up of 13 exons separated by variably sized introns making it over $15 \mathrm{~kb}$ in length[40].
This complex multi-intronic gene structure (a hallmark of family B GPCRs) allows for multiple alternative receptor splice forms and also can give rise to mutations caused by splicing errors.

GHRH-R mRNA is expressed predominantly in the pituitary with lesser amounts found in the hypothalamus and other areas of the brain. By Northern blot, the GHRH-R is also expressed in the placenta, kidney, testis and digestive tract where its function is not well understood[41].

\section{Where on the GHRH-R does GHRH Bind?}

For some family A GPCRs there is clear crystal structure evidence that the seven transmenbrane helices form a bundle surrounding a binding pocket where small ligands can fit in and trigger activation of intracellular $G$ proteins[42]. But for other GPCRs, including those that are activated by larger ligands, there is evidence that the extracellular domain is the hormone binding site[43]. For family $\mathrm{B}$ receptors the structure of the transmembranes helices is assumed to be similar to family A, but no high resolution structure been demonstrated. Family B1 receptor ligands are helical peptides too large to fit in a transmembrane binding pocket. These receptors have relatively large extracellular domains, so it is not clear from their structure which of these receptor domains interact with the hormone ligand.

Structure/function studies of the GHRH peptide show that only the N-terminal 29 amino acids are necessary for full receptor activation[44]. Some GHRH analogs with D-arginine at position 2 have been found to act as antagonists[45]. This suggests that the $\mathrm{N}$-terminal end of the peptide is crucial for receptor activation. Substitutions that stabilize the helical structure of the GHRH peptide can enhance its receptor binding affinity suggesting that the bound form of GHRH is helical[46].

The GHRH-R has a large N-terminal extracellular domain attached to the seven transmembrane bundle (Fig. 2). Studies of chimeric receptors in which the extracellular and tranmembrane domains were exchanged among the closely related GHRH, VIP and secretin receptors were used to examine which of these domains determine ligand specificity[47]. The results show that neither the extracellular nor transmembrane receptor domains when expressed separately could bind hormone. The chimeric 
- Bruce Gaylinn: Current Research on the Structure and Function of the Growth Hormone Releasing Hormone Receptor -



Fig. 2. Cartoon model of GHRH-R structure showing sites of photoaffinity cross-linking. With GHRH bound to wild type receptor, cross-linkers at GHRH position 12 lie in close proximity to the stippled region, while linkers at GHRH positions 1 and 21 are close to different sites in the gray region. The single N-linked extracellular glycosylation site is shown at N. D indicates the site of a $D$ to $G$ point mutation (Asp60-Gly) that disrupts ligand binding in the lit mutant.

receptor constructs suggest that determinants from both the transmembranes and the extracellular domains may interact with the ligand, as no single domain predicted the function or specificity of the chimeras.

An alternative approach to determining the sites of receptor-hormone interaction is photo-affinity cross-linking. Here the radiolabeled hormone is modified with UV -activatable cross-linking groups at different sites along the hormone sequence. The hormone is then bound to its receptor and irradiated with UV light causing covalent cross-linking of the bound hormone to the receptor. The cross-linked complex is then protease digested to allow the identification of receptor sites in close contact to the bound hormone. We prepared iodinated GHRH with cross-linking groups at positions 1, 12 and 21[48]. The results suggest that the mid region of GHRH is in close proximity to the region just extracellular to transmembrane 1 , while the $\mathrm{N}$ - and $\mathrm{C}$-terminal ends of GHRH are close to domains in the C-terminal half of the receptor (Fig. 2), consistent with the N-terminus of GHRH fitting into a transmembrane pocket. Studies of other receptors in this family have suggested similar models with the hormone's $\mathrm{N}$-terminus buried in the receptor transmembrane domain and the remainder of the hormone peptide helix coordinating with extracellular domains[49]. But other models, such as a two step process with binding first to an extrcellular domain and then to a transmembrane domain, can not be ruled out[50].

\section{Loss of Function Receptor Mutants}

The lit mouse is a naturally occurring GH deficient dwarf strain with reduced numbers of pituitary somatotrophs[51]. Because these mice did not respond to GHRH but their pituitary cells could release $\mathrm{GH}$ in response to activators of CAMP, it was proposed that the lit mouse might lack GHRH-R[52,53]. After the GHRH receptor was cloned, it was demonstrated that these lit mice had a point mutation in a conserved amino acid in the receptor's extracellular domain (Asp60-Gly) (Fig. 2) $[7,8]$. This defective receptor protein is produced and localized to the cell membrane, but is unable to bind GHRH[54]. Crystallographic studies of the bacterially expressed extracellular domain from the homologous CRH receptor propose that this charged aspartic acid residue is required for a salt bridge that is key to the extracellular domain structure[49].

Subsequent studies in human GH deficient patients have led to the identification of several GHRH-R inactivating mutations (Fig. 3) including one in a kindred of over 100 affected individuals[13]. It is now suggested that $10 \%$ of all human familial isolated GH deficiency type 1 is caused by GHRH-R defects[14,55]. It has also been hypothesized that activating mutations of the GHRH-R could be involved in the generation of pituitary tumors. Studies of the GHRH-R from tumors of acromegatics and other patients have failed to detect any such mutations, suggesting that activating GHRH-R mutations are at best very rare[56,57].

\section{Dominant Negative GHRH-Rs}

An alternatively spliced mRNA encoding a GHRH-R with only the first 5 transmembrane helices is seen in normal pituitary and is more abundant in some pituitary tumors[58]. This truncated receptor (Fig. 4) was shown not to function in cAMP signaling in response to GHRH 




Fig. 3. Sites of mutations reported to affect GHRH-R function. P1 to P9 are the sites of reported receptor point mutations resulting in single amino acid substitutions. T1 to T8 are sites of reported truncations. T1- Truncation found in a Brazilian kindred with over 105 effected individuals.



Fig. 4. Cartoon illustrated the GHRH-R truncations mutants found to have dominant negative activity.

and when it was co-expressed with wild-type receptor, it appeared to inhibit cAMP signaling[59]. This has been examined in more detail in a recent study using epitope tagged receptors[60] where it was found that the truncated receptor protein is expressed and associates with the wild-type receptor in some sort of multimer complex, where it blocks receptor signaling in a dominant negative fashion. We have examined a different GHRH-R truncation mutant found in a $\mathrm{GH}$ deficient patient from Japan[61]. While this patient was homozygous for the mutation and was severely affected, heterozygous family members also appeared of short stature, but to a lesser extent. The small population size and partial phenotype expected made it impossible to demonstrate a statistically significant heterzygote effect. This mutant receptor is truncated within transmembrane 7 (Fig. 4) and is not able to bind GHRH or signal cAMP, but like the more severe truncation just discussed, it also interferes with the
GHRH

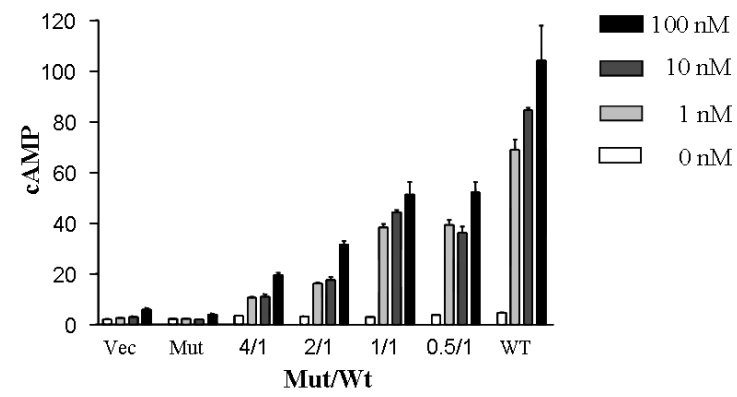

Fig. 5. cAMP signaling from the wild-type receptor is inhibited in proportion to the amount of the truncation mutant expressed.

function of the wild-type receptor in-vitro[62] (Fig. 5). These data suggest the hypothesis that the GHRH-R functional unit might be a dimer such that the presence of a bad partner could prevent the action of an associated good receptor. While heterozygote lit/+ mice are of normal size, and no phenotype has been demonstrated in heterozygotes for human GHRH-R inactivating mutations, it is possible that some specific receptor truncation mutations could cause reduced height in heterzygotes due to this dominant negative effect.

\section{The GHRH-R of Sheep is Truncated}

To help in our studies of receptor structure/function we cloned the GHRH-R from ovine pituitary[63]. The mRNA we identified was very homologous to that of human and 
- Bruce Gaylinn: Current Research on the Structure and Function of the Growth Hormone Releasing Hormone Receptor -



Fig. 6. Sensitivity for GHRH activation of cAMP signaling is increased ten fold when the human GHRH-R is truncated by 16 amino acids.

rat, but encoded a receptor lacking the last 16 amino acids of the C-terminal intracellular tail. The identical mRNA was also found in sheep of a different breed, and no message for the full-length receptor could be identified. In contrast, we cloned the bovine receptor and found that it did not share this truncation. To establish that this was not a cloning artifact, we examined receptor protein expressed in bovine and ovine pituitaries. As predicted, the GHRH-R of sheep pituitary had the appropriately lower molecular weight on SDS gels. When the ovine receptor was transiently transfected in cell lines, we found that it's affinity for GHRH binding was the same as the human or bovine receptors, but it was $\sim 10$ fold more sensitive to GHRH in cAMP signaling assays. When the analogous truncation was put in the human receptor, it too became similarly more sensitive to GHRH in cAMP signaling assays (Fig. 6). This suggests that this C-terminal domain inhibits receptor signaling. This is consistent with results found for other receptors showing that phosphorylation of a C-terminal domain can be involved in receptor down regulation and internalization. This region of the GHRH receptor contains multiple potential phosphorylation sites and ${ }^{32} \mathrm{P}$ incorporation studies suggest GHRH stimulated GHRH-R phosphorylation[64].

This potentiated receptor in domestic sheep brings up an interesting hypothesis. Could the establishment of this mutated GHRH-R be the result of man's selection for animals with increased milk, meat and hair production? To answer this question we examined the GHRH-R of goats. We found that goats share the identical truncation found in sheep. Therefore, the mutation must have occurred millions of years ago in the common ancestor of goats and sheep and long before man's influence.

\section{Mitogenic Signaling, Autocrine/Paracrine Effects and Tumor Growth}

In vivo, decreased GHRH signaling due to inactivating GHRH-R mutation[7,65], perinatal administration of GHRH antisera[66], or knock out of the GHRH gene[14] all result in somatotroph hypoplasia. Increased GHRH signaling caused by GHRH over production by an ectopic tumor[67], activating mutations of the $G$ protein $G_{s}[68]$, or transgenic over-expression of GHRH[69] all result in somatotroph hyperplasia. In-vitro, GHRH is a mitogenic factor for somatotroph proliferation[29]. This mitogenic action would not be expected from the cAMP PKA signaling pathway known for the GHRH-R. More recent studies have demonstrated that the GHRH-R also couples to the MAP kinase stimulating the activation of ERK1 and ERK2 via a pathway that may act through the $G$ protein fy subunits[4,70,71]. It is hypothesized that this MAP kinase pathway is the mechanism for GHRH's mitogenic effects.

Several studies have found that synthetic GHRH antagonists can inhibit the growth and proliferation of a wide variety of human tumors and tumor cell lines. This inhibition can be demonstrated both in in-vitro models of tumor growth and also in-vivo when tumors are xenografted into nude mice[72 76]. Human small cell carcinoma of the lung, breast cancer lines, osteosarcomas, and prostate cancer cell lines were all inhibited. This antiproliferative effect of GHRH antagonists is consistent with the hypothesis that GHRH can act as a local autocrine/paracrine factor in the stimulation of cell growth[31] and with the mitogenic actions of GHRH at the somatotroph[29]. The mechanism for this action has been unclear because studies using PCR could not detect 




Fig. 7. Illustration of GHRH-R splice variants SV-1, SV-2, SV-3 and SV-4. Regions encoded by intronic sequence not part of the pituitary receptor are shown striped, black regions are shared with the pituitary receptor; grey shows the signal peptide of the pituitary receptor.

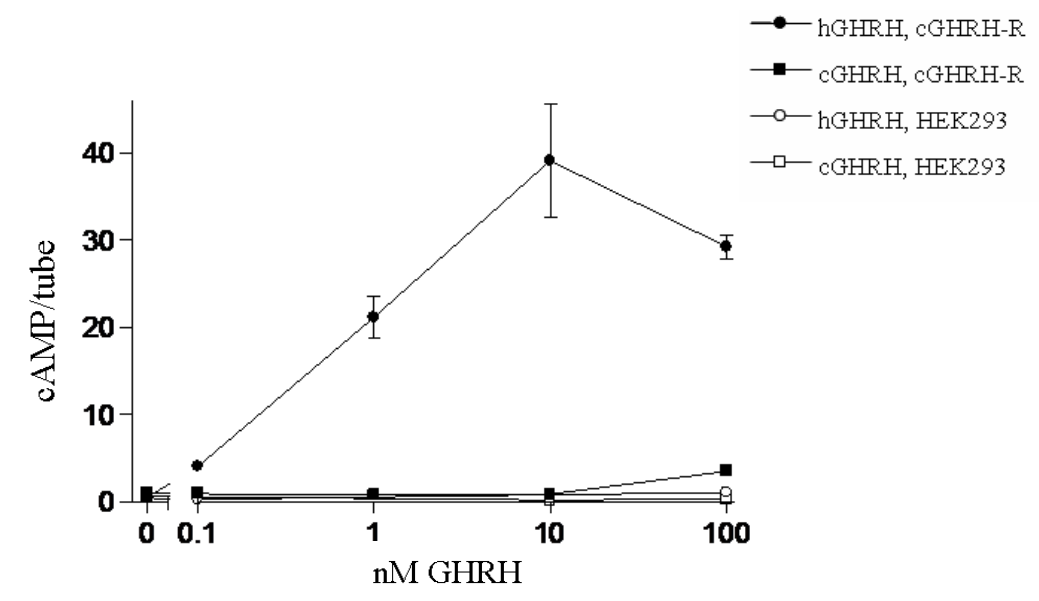

Fig. 8. cAMP activation by human or chicken GHRH at HEK293 cells with and without transfection with chicken GHRH receptor.

full length GHRH-R in these cell lines responsive to GHRH antagonist[74]. Instead it was discovered that these tumor cells, and also some normal normal tissues such as human prostate, express alternatively spliced forms of GHRH-R messages not found in pituitary[74,77]. These alternatively spliced mRNAs encode shortened receptor splice variant proteins that were named SV1, SV2 and SV3. The major predicted splice variant, SV1 initiates at a putative alternative start codon within intron 3. In SV1 the first 87 amino acids of the normal 128 amino acid receptor $\mathrm{N}$-terminal extracellular domain are replaced by a new 26 amino acid sequence with the remainder of the receptor unchanged (Fig. 7). In-vitro studies find that this new receptor with a smaller alternative extracellular domain is still able to bind GHRH analogs[78]. The presence of SV1 message in tumor lines correlates with their response to antagonists[74]. Thus GHRH antagonist, by blocking the actions of this alternatively spliced receptor, may prove to be useful agents against a wide variety of cancers.

\section{GHRH in Birds?}

GHRH and PACAP-like peptides highly similar to those in mammals are found in a protocordate invertebrate where their function is unknown as no $\mathrm{GH}$ has been identified in these species[79]. GHRH-like peptides are found in fish, but their function as the regulator of $\mathrm{GH}$ 
- Bruce Gaylinn: Current Research on the Structure and Function of the Growth Hormone Releasing Hormone Receptor -

secretion is unclear as PACAP seems a better candidate for that role[80]. In birds, GnRH, TRH and dopamine are potent stimulators of $\mathrm{GH}$ release and PACAP has only low potency[81]. A GHRH-like peptide has been identified in chicken[82], but it does not cause GH release in live animals or stimulate in-vitro preparations of chicken pituitary[83]. But, in the same studies, mammalian GHRH is a very potent GH releaser in chickens, both in-vivo and in-vitro.

To try to understand this contradiction, we cloned the chicken GHRH-R[84]. This receptor is intermediate in sequence between the known GHRH-Rs of mammals and fish, and distinct from related receptors for other ligands. When the recombinant chicken receptor was expressed in cell lines, it bound human GHRH with high affinity and signaled cAMP accumulation (Fig. 8). But this receptor did not respond to the known chicken GHRH and only very weakly responded to related peptides like VIP and PACAP. When we examined membranes from chicken pituitary, we found that the endogenous chicken receptor bound human GHRH but not the chicken GHRH-like peptide. Thus our cloned receptor behaved exactly like the endogenous chicken GHRH-R and we hypothesized that there was some problem with the chicken GHRH we had tested. Mass spectrometry showed that our peptide stock was not cleaved or degraded and was present at the expected concentration, so we re-cloned the GHRH-like peptide from chicken hypothalamus and found that it did not agree with the published sequence. A lysine (Lys21) that is conserved in GHRH-like peptides from all other known species was not conserved in the published chicken GHRH sequence. In our hands, this conserved lysine was also conserved in chickens. When we tested Lys21 chicken GHRH on the recombinant chicken receptor, on chicken pituitaries, and in live chickens, we were disappointed. This new peptide was more active than before, but only weakly active with no more potency than PACAP and dramatically less potency than human GHRH. Thus the puzzle of the GHRH system in birds is not yet solved but we hypothesize that the problem is with the chicken GHRH-like peptide and we are currently testing potential solutions.

\section{References}

1. Gaylinn BD, Harrison JK, Zysk JR, Lyons CE, Lynch
KR, Thorner MO: Molecular cloning and expression of a human anterior pituitary receptor for growth hormone-releasing hormone. Mol Endocrinol 7:77-84, 1993

2. Mayo KE: Molecular cloning and expression of a pituitary-specific receptor for growth hormone -releasing hormone. Mol Endocrinol 6:1734-1744, 1992

3. Frohman LA, Jansson JO: Growth hormone-releasing hormone. Endocr Rev 7:223-253, 1986

4. Mayo KE, Miller T, DeAlmeida V, Godfrey P, Zheng J, Cunha SR: Regulation of the pituitary somatotroph cell by GHRH and its receptor. Recent Prog Horm Res 55:237-266, 2000

5. Goth MI, Lyons CE, Canny BJ, Thorner MO: Pituitary adenylate cyclase activating polypeptide, growth hormone (GH)-releasing peptide and GH-releasing hormone stimulate $\mathrm{GH}$ release through distinct pituitary receptors. Endocrinology 130:939-944, 1992

6. Cella SG, De Gennaro Colonna V, Locatelli V, Bestetti GE, Rossi GL, Torsello A, Wehrenberg WB, Muller EE: Somatotropic dysfunction in growth hormone-releasing hormone-deprived neonatal rats: effect of growth hormone replacement therapy. Pediatr Res 36:315-322, 1994

7. Lin SC, Lin CR, Gukovsky I, Lusis AJ, Sawchenko PE, Rosenfeld MG: Molecular basis of the little mouse phenotype and implications for cell type-specific growth. Nature 364:208-213, 1993

8. Godfrey P, Rahal JO, Beamer WG, Copeland NG, Jenkins NA, Mayo KE: GHRH receptor of little mice contains a missense mutation in the extracellular domain that disrupts receptor function. Nat Genet 4:227-232, 1993

9. Wajnrajch MP, Gertner JM, Harbison MD, Chua SC $\mathrm{Jr}$, Leibel RL: Nonsense mutation in the human growth hormone-releasing hormone receptor causes growth failure analogous to the little (lit) mouse. Nat Genet 12:88-90, 1996

10. Baumann G, Maheshwari H: The Dwarfs of Sindh: severe growth hormone (GH) deficiency caused by a mutation in the GH-releasing hormone receptor gene. Acta Paediatr Suppl 423:33-38, 1997

11. Maheshwari HG, Silverman BL, Dupuis J, Baumann G: Phenotype and genetic analysis of a syndrome caused by an inactivating mutation in the growth 
hormone-releasing hormone receptor: Dwarfism of Sindh. J Clin Endocrinol Metab 83:4065-4074, 1998

12. Netchine I, Talon P, Dastot F, Vitaux F, Goossens M, Amselem S: Extensive phenotypic analysis of a family with growth hormone (GH) deficiency caused by a mutation in the GH-releasing hormone receptor gene. J Clin Endocrinol Metab 83:432-436, 1998

13. Salvatori R, Hayashida CY, Aguiar-Oliveira $\mathrm{MH}$, Phillips JA 3rd, Souza AH, Gondo RG, Toledo SP, Conceicao MM, Prince M, Maheshwari HG, Baumann G, Levine MA: Familial dwarfism due to a novel mutation of the growth hormone-releasing hormone receptor gene. J Clin Endocrinol Metab 84:917-923, 1999

14. Alba M, Salvatori R: Familial growth hormone deficiency and mutations in the GHRH receptor gene. Vitam Horm 69:209-220, 2004

15. Salomon F, Cuneo RC, Hesp R, Sonksen PH: The effects of treatment with recombinant human growth hormone on body composition and metabolism in adults with growth hormone deficiency. N Engl J Med 321:1797-1803, 1989

16. Bengtsson BA, Eden S, Lonn L, Kvist H, Stokland A, Lindstedt G, Bosaeus I, Tolli J, Sjostrom L, Isaksson OG: Treatment of adults with growth hormone (GH) deficiency with recombinant human GH. J Clin Endocrinol Metab 76:309-317, 1993

17. Sartorio A, Ortolani S, Conti A, Cherubini R, Galbiati E, Faglia G: Effects of recombinant growth hormone (GH) treatment on bone mineral density and body composition in adults with childhood onset growth hormone deficiency. J Endocrinol Invest 19:524-529, 1996

18. O'Halloran DJ, Tsatsoulis A, Whitehouse RW, Holmes SJ, Adams JE, Shalet SM: Increased bone density after recombinant human growth hormone (GH) therapy in adults with isolated GH deficiency. J Clin Endocrinol Metab 76:1344-1348, 1993

19. Auernhammer CJ, Strasburger CJ: Effects of growth hormone and insulin-like growth factor $\mathrm{I}$ on the immune system. Eur J Endocrinol 133:635-645, 1995

20. Lal SO, Wolf SE, Herndon DN: Growth hormone, burns and tissue healing. Growth Horm IGF Res 10(Suppl B):S39-43, 2000

21. Colao A, Marzullo P, Di Somma C, Lombardi G: Growth hormone and the heart. Clin Endocrinol 54:
137-154, 2001

22. Napoli R, Guardasole V, Matarazzo M, Palmieri EA, Oliviero U, Fazio S, Sacca L: Growth hormone corrects vascular dysfunction in patients with chronic heart failure. J Am Coll Cardiol 39:90-95, 2002

23. Lange M, Thulesen J, Feldt-Rasmussen U, Skakkebaek NE, Vahl N, Jorgensen JO, Christiansen JS, Poulsen SS, Sneppen SB, Juul A: Skin morphological changes in growth hormone deficiency and acromegaly. Eur J Endocrinol 145:147-153, 2001

24. Van Cauter E, Plat L, Copinschi G: Interrelations between sleep and the somatotropic axis. Sleep 21:553-566, 1998

25. Beshyah SA, Freemantle C, Shahi M, Anyaoku V, Merson S, Lynch S, Skinner E, Sharp P, Foale R, Johnston DG: Replacement treatment with biosynthetic human growth hormone in growth hormone-deficient hypopituitary adults. Clin Endocrinol 42:73-84, 1995

26. Murray RD, Darzy KH, Gleeson HK, Shalet SM: GH-deficient survivors of childhood cancer: GH replacement during adult life. J Clin Endocrinol Metab 87:129-135, 2002

27. Vance ML: Nutrition, body composition, physical activity and growth hormone secretion. J Pediatr Endocrinol 9(Suppl 3):299-301, 1996

28. Johannsson G, Svensson J, Bengtsson BA: Growth hormone and ageing. Growth Horm IGF Res 10(Suppl B):S25-30, 2000

29. Billestrup N, Swanson LW, Vale W: Growth hormone-releasing factor stimulates proliferation of somatotrophs in vitro. Proc Natl Acad Sci USA 83:6854-6857, 1986

30. Csernus V, Schally AV, Groot K: Antagonistic analogs of growth hormone releasing hormone (GHRH) inhibit cyclic AMP production of human cancer cell lines in vitro. Peptides 20:843-850, 1999

31. Kineman RD: Antitumorigenic actions of growth hormone-releasing hormone antagonists. Proc Natl Acad Sci USA 97:532-534, 2000

32. Kiaris H, Schally AV, Kalofoutis A: Extrapituitary effects of the growth hormone-releasing hormone. Vitam Horm 70:1-24, 2005

33. Harmar AJ: Family-B G-protein-coupled receptors. Genome Biol 2:Reviews3013.1-3013.10, 2001

34. Fredriksson R, Schioth HB: The repertoire of G-protein-coupled receptors in fully sequenced 
- Bruce Gaylinn: Current Research on the Structure and Function of the Growth Hormone Releasing Hormone Receptor -

genomes. Mol Pharmacol 67:1414-1425, 2005

35. Christophe J: The VIP/PHI/secretin/helodermin/helospectin/ GRF family: structure-function relationships of the natural peptides, their precursors and synthetic analogues as tested in vitro on receptors and adenylate cyclase in a panel of tissue membranes. In: Martinez J ed. Peptide Hormones as Prohormones: Processing, Biological Activity, Pharmacology. pp211-243, Chichester [England], E. Horwood, New York, Halsted Press, 1989

36. Bell GI: The glucagon superfamily: precursor structure and gene organization. Peptides 7(Suppl 1):27-36, 1986

37. Campbell RM, Scanes CG: Evolution of the growth hormone-releasing factor (GRF) family of peptides. Growth Regul 2:175-191, 1992

38. Ishihara $\mathrm{T}$, Nakamura $\mathrm{S}$, Kaziro $\mathrm{Y}$, Takahashi $\mathrm{T}$, Takahashi K, Nagata S: Molecular cloning and expression of a cDNA encoding the secretin receptor. EMBO J 10:1635-1641, 1991

39. Lin $\mathrm{C}$, Lin SC, Chang $\mathrm{CP}$, Rosenfeld MG: Pit-1-dependent expression of the receptor for growth hormone releasing factor mediates pituitary cell growth. Nature 360:765-768, 1992

40. Andrews S, Dubbelde C, Ryan E: The sequence of Homo sapians PAC clone DJ0877J02, GenBank accession No. AC005155. US National Center for Biotechnology Information, National Library of Medicine/National Institutes of Health at http: //www.ncbi.nlm.gov/, 1998

41. Mayo KE, Miller TL, DeAlmeida V, Zheng J, Godfrey PA: The growth-hormone-releasing hormone receptor: signal transduction, gene expression, and physiological function in growth regulation. Ann N Y Acad Sci 805:184-203, 1996

42. Palczewski K, Kumasaka T, Hori T, Behnke CA, Motoshima H, Fox BA, Le Trong I, Teller DC, Okada T, Stenkamp RE, Yamamoto M, Miyano M: Crystal structure of rhodopsin: A G protein-coupled receptor. Science 289:739-745, 2000

43. Dias JA, Van Roey P: Structural biology of human follitropin and its receptor. Arch Med Res 32:510-519, 2001

44. Campbell RM, Bongers J, Felix AM: Rational design, synthesis, and biological evaluation of novel growth hormone releasing factor analogues. Biopolymers 37 :
67-88, 1995

45. Robberecht P, Coy DH, Waelbroeck M, Heiman ML, de Neef P, Camus JC, Christophe J: Structural requirements for the activation of rat anterior pituitary adenylate cyclase by growth hormone-releasing factor (GRF): discovery of (N-Ac-Tyr1, D-Arg2)-GRF (1-29)-NH2 as a GRF antagonist on membranes. Endocrinology 117:1759-1764, 1985

46. Coy DH, Hocart SJ, Murphy WA: Human growth hormone-releasing hormone analogues with much improved in vitro growth hormone-releasing potencies in rat pituitary cells. Eur J Pharmacol 204:179-185, 1991

47. DeAlmeida VI, Mayo KE: Identification of binding domains of the growth hormone-releasing hormone receptor by analysis of mutant and chimeric receptor proteins. Mol Endocrinol 12:750-765, 1998

48. Gaylinn BD, Lyons CE, Thorner MO: Mapping of the GHRH receptor binding site by photoaffinity crosslinking from different residues of GHRH. In the 79th Annual Meeting of Endocrine Society. Minneapolis, USA, 1997

49. Grace CR, Perrin MH, DiGruccio MR, Miller CL, Rivier JE, Vale WW, Riek R: NMR structure and peptide hormone binding site of the first extracellular domain of a type B1 G protein-coupled receptor. Proc Natl Acad Sci USA 101:12836-12841, 2004

50. Gershengorn MC, Osman R: Minireview: Insights into $\mathrm{G}$ protein-coupled receptor function using molecular models. Endocrinology 142:2-10, 2001

51. Eicher EM, Beamer WG: Inherited ateliotic dwarfism in mice. Characteristics of the mutation, little, on chromosome 6. J Hered 67:87-91, 1976

52. Clark RG, Robinson IC: Effects of a fragment of human growth hormone-releasing factor in normal and 'Little' mice. J Endocrinol 106:1-5, 1985

53. Jansson JO, Downs TR, Beamer WG, Frohman LA: Receptor-associated resistance to growth hormonereleasing factor in dwarf "little" mice. Science 232: 511-512, 1986

54. Gaylinn BD, Dealmeida VI, Lyons CE Jr, Wu KC, Mayo KE, Thorner MO: The mutant growth hormone-releasing hormone (GHRH) receptor of the little mouse does not bind GHRH. Endocrinology 140:5066-5074, 1999

55. Salvatori R, Fan X, Phillips JA 3rd, Prince M, Levine 
MA: Isolated growth hormone (GH) deficiency due to compound heterozygosity for two new mutations in the GH-releasing hormone receptor gene. Clin Endocrinol 54:681-687, 2001

56. Lee EJ, Duan WR, Kotlar T, Jameson JL: Restoration of growth hormone-releasing hormone (GHRH) responsiveness in pituitary GH3 cells by adenovirus-directed expression of the human GHRH receptor. Endocrinology 142:414-420, 2001

57. Salvatori R, Thakker RV, Lopes MB, Fan X, Eswara JR, Ellison D, Lees P, Harding B, Yang I, Levine MA: Absence of mutations in the growth hormone (GH)-releasing hormone receptor gene in GH-secreting pituitary adenomas. Clin Endocrinol 54:301-307, 2001

58. Tang J, Lagace G, Castagne J, Collu R: Identification of human growth hormone-releasing hormone receptor splicing variants. J Clin Endocrinol Metab 80:23812387, 1995

59. Motomura $\mathrm{T}$, Hashimoto $\mathrm{K}$, Koga $\mathrm{M}$, Arita $\mathrm{N}$, Hayakawa T, Kishimoto T, Kasayama S: Inhibition of signal transduction by a splice variant of the growth hormone-releasing hormone receptor expressed in human pituitary adenomas. Metabolism 47:804-808, 1998

60. McElvaine AT, Mayo KE: A dominant-negative human growth hormone-releasing hormone (GHRH) receptor splice variant inhibits GHRH binding. Endocrinology 147:1884-1894, 2006

61. Horikawa $\mathrm{H}$ : Isolated $\mathrm{GH}$ deficiency due to inactivating mutation of GHRH receptor. Nippon Rinsho 60:297-305, 2002

62. Horikawa R: A growth hormone-releasing hormone (GHRH) receptor mutation that acts as a doninant negative. In the 83rd Annual Meeting of Endocrine Society. Denver, USA, 2001

63. Horikawa R, Gaylinn BD, Lyons CE Jr, Thorner MO: Molecular cloning of ovine and bovine growth hormone-releasing hormone receptors: the ovine receptor is C-terminally truncated. Endocrinology 142:2660-2668, 2001

64. Gaylinn BD, Lyons CE, Thorner MO: Internalization and phosphorylation of GHRH receptor. In the 80th Annual Meeting of Endocrine Society. New Orleans, USA, 1998

65. Murray RA, Maheshwari HG, Russell EJ, Baumann G: Pituitary hypoplasia in patients with a mutation in the growth hormone-releasing hormone receptor gene. AJNR Am J Neuroradiol 21:685-689, 2000

66. Cella SG, Locatelli V, Broccia ML, Menegola E, Giavini E, De Gennaro Colonna V, Torsello A, Wehrenberg WB, Muller EE: Long-term changes of somatotrophic function induced by deprivation of growth hormone-releasing hormone during the fetal life of the rat. J Endocrinol 140:111-117, 1994

67. Thorner MO, Perryman RL, Cronin MJ, Draznin MB, Johanson AJ, Rogol AD, Jane JA, Rudolf LE, Horvath E, Kovacs K, Vale W: Somatotroph hyperplasia: successful treatment of acromegaly by removal of a pancreatic islet tumor secreting a growth hormonereleasing factor. Trans Assoc Am Physicians 95:177187, 1982

68. Landis CA, Masters SB, Spada A, Pace AM, Bourne HR, Vallar L: GTPase inhibiting mutations activate the alpha chain of Gs and stimulate adenylyl cyclase in human pituitary tumours. Nature 340:692-696, 1989

69. Lloyd RV, Jin L, Chang A, Kulig E, Camper SA, Ross BD, Downs TR, Frohman LA: Morphologic effects of hGRH gene expression on the pituitary, liver, and pancreas of MT-hGRH transgenic mice. An in situ hybridization analysis. Am J Pathol 141:895906, 1992

70. Pombo CM, Zalvide J, Gaylinn BD, Dieguez C: Growth hormone-releasing hormone stimulates mitogen-activated protein kinase. Endocrinology 141: 2113-2119, 2000

71. Zeitler P, Siriwardana G: Stimulation of mitogenactivated protein kinase pathway in rat somatotrophs by growth hormone-releasing hormone. Endocrine 12:257-264, 2000

72. Kiaris H, Schally AV, Armatis P: Direct action of growth hormone-releasing hormone agonist JI-38 on normal human fibroblasts: evidence from studies on cell proliferation and c-myc proto-oncogene expression. Regul Pept 96:119-124, 2001

73. Kiaris H, Schally AV, Varga JL: Suppression of tumor growth by growth hormone-releasing hormone antagonist JV-1-36 does not involve the inhibition of autocrine production of insulin-like growth factor II in H-69 small cell lung carcinoma. Cancer Lett 161:149155, 2000

74. Rekasi Z, Czompoly T, Schally AV, Halmos G: Isolation and sequencing of cDNAs for splice variants 
- Bruce Gaylinn: Current Research on the Structure and Function of the Growth Hormone Releasing Hormone Receptor -

of growth hormone-releasing hormone receptors from human cancers. Proc Natl Acad Sci USA 97:1056110566, 2000

75. Halmos G, Schally AV, Varga JL, Plonowski A, Rekasi Z, Czompoly T: Human renal cell carcinoma expresses distinct binding sites for growth hormone-releasing hormone. Proc Natl Acad Sci USA 97:10555-10560, 2000

76. Kiaris H, Schally AV, Varga JL, Groot K, Armatis P: Growth hormone-releasing hormone: an autocrine growth factor for small cell lung carcinoma. Proc Natl Acad Sci USA 96:14894-14898, 1999

77. Chopin LK, Herington AC: A potential autocrine pathway for growth hormone releasing hormone (GHRH) and its receptor in human prostate cancer cell lines. Prostate 49:116-121, 2001

78. Kiaris H, Schally AV, Busto R, Halmos G, Artavanis-Tsakonas S, Varga JL: Expression of a splice variant of the receptor for GHRH in 3T3 fibroblasts activates cell proliferation responses to GHRH analogs. Proc Natl Acad Sci USA 99:196-200, 2002

79. Sherwood NM, Krueckl SL, McRory JE: The origin and function of the pituitary adenylate cyclase- activating polypeptide (PACAP)/glucagon superfamily. Endocr Rev 21:619-670, 2000

80. Wong AO, Li WS, Lee EK, Leung MY, Tse LY, Chow BK, Lin HR, Chang JP: Pituitary adenylate cyclase activating polypeptide as a novel hypophysiotropic factor in fish. Biochem Cell Biol 78: 329-343, 2000

81. Harvey S, Fraser RA, Lea R: Growth hormone secretion in poultry. Crit Rev Poult Biol 3:239-282, 1991

82. McRory JE, Parker RL, Sherwood NM: Expression and alternative processing of a chicken gene encoding both growth hormone-releasing hormone and pituitary adenylate cyclase-activating polypeptide. DNA Cell Biol 16:95-102, 1997

83. Harvey S: GHRH: a GH releasing factor in birds? Neural regulation in the vertebrate endocrine system. pp69-83, New York, Kluwer Academic/Plenum Publishers, 1999

84. Toogood AA, Harvey S, Thorner MO, Gaylinn BD: Cloning of the chicken pituitary receptor for growth hormone-releasing hormone. Endocrinology 147:18381846, 2006 